\title{
Reactivity and fate of secondary alkane sulfonates (SAS) in marine sediments
}

\author{
Rosa María Baena-Nogueras a , Patricia Rojas-Ojeda ${ }^{b}$, José Luis Sanz ${ }^{\text {, }}$, \\ Eduardo González-Mazo a , Pablo A. Lara-Martín ${ }^{\mathrm{a}, *}$ \\ ${ }^{a}$ Departamento de Química-Física, Facultad de Ciencias del Mar y Ambientales, Universidad de Cádiz, Campus de Excelencia Internacional del Mar \\ (CEI·MAR), Campus de Río San Pedro s/n, 11510 Puerto Real, Cádiz, Spain \\ ${ }^{\mathrm{b}}$ Unidad de Microbiología Aplicada, Centro de Biología Molecular, Universidad Autónoma de Madrid, Crta. De Colmenar km 15, 28049 Madrid, Spain
}

\section{A R T I C L E I N F O}

\section{Article history:}

Received 20 November 2013

Received in revised form

13 February 2014

Accepted 16 February 2014

\section{Keywords:}

Sorption

Bioavailability

Biodegradation

Surfactants

Sediment

Metabolites

\begin{abstract}
A B S T R A C T
This research is focused on secondary alkane sulfonates (SAS), anionic surfactants widely used in household applications that access aquatic environments mainly via sewage discharges. We studied their sorption capacity and anaerobic degradation in marine sediments, providing the first data available on this topic. SAS partition coefficients increased towards those homologues having longer alkyl chains (from up to $141 \mathrm{~L} \mathrm{~kg}^{-1}$ for $C_{14}$ to up to $1753 \mathrm{~L} \mathrm{~kg}^{-1}$ for $C_{17}$ ), which were those less susceptible to undergo biodegradation. Overall, SAS removal percentages reached up to $98 \%$ after 166 days of incubation using anoxic sediments. The degradation pathway consisted on the formation of sulfocarboxylic acids after an initial fumarate attack of the alkyl chain and successive $\beta$-oxidations. This is the first study showing that SAS can be degraded in absence of oxygen, so this new information should be taken into account for future environmental risk assessments on these chemicals.
\end{abstract}

(c) 2014 Elsevier Ltd. All rights reserved.

\section{Introduction}

Wastewater discharges are one of the major sources of contamination affecting aquatic systems. Among the different organic contaminants that can be detected in sewage, surfactants are often present at the highest concentrations due to their extensive use in many household and industrial applications as detergents, emulsifiers, wetting agents, etc. (Kolpin et al., 2002). Many studies deal with the occurrence, distribution and behaviour of these compounds in the receiving waters (rivers, lakes, coastal environments) (Lara-Martín et al., 2008a), although most of them are focused on two specific surfactants: linear alkylbenzene sulfonates (LAS) and nonylphenol ethoxylates (NPEO). There are, therefore, many other surfactants that, in spite of being also widely used, have received less attention by the scientific community and hence, available environmental information on them is scarce or non-existent. This article discusses the reactivity and fate of secondary alkane sulfonates (SAS) in the marine environment. Nowadays, SAS are one of the major anionic surfactants used in the market of dishwashing,

\footnotetext{
* Corresponding author.

E-mail address: pablo.lara@uca.es (P.A. Lara-Martín).
}

laundry and cleaning products. European production of SAS is approximately 66000 tons/year (HERA project, 2005). SAS is commercially available as different mixtures of homologues having from 14 to 17 carbon units (linearity of the alkyl chain $>98 \%$ ), with an average of 15.9 carbon atoms and molecular weight of 328 Da.

Field and co-workers carried out several studies (Field et al., 1994, 1995) on the efficiency of wastewater treatment plants (WWTP) removing SAS. This surfactant was efficiently removed (95-99\%), mainly through aerobic biodegradation during secondary treatment (84\%). However, the degradation pathway of SAS is still unclear. So far, Thysse and Wanders (1974) identified 2-dodecane as a possible metabolite for the degradation of $C_{12}$ SAS. Swisher (1964) also suggested that the first step in the pathway could be the formation of a ketobisulfite. The rest of the total amount of SAS entering WWTP (16\%) is transferred to the sludge, where these surfactants appear to remain stable even after anaerobic digestion (Field et al., 1995). This was confirmed in a later study (Bruno et al., 2002) where removal rates for SAS in sludge were only between 5 and 13\% after 14 days of anaerobic digestion. More recently, our research group has found concentrations up to $2.8 \mathrm{mg} \mathrm{kg}^{-1}$ in sludge from Puerto Real WWTP (SW Spain). SAS has also been detected in surface sediments from the Guadalete River (SW Spain) in a range between 72 and $9737 \mu \mathrm{g} \mathrm{kg}^{-1}$ (Baena-Nogueras et al., 2013) vs. 1 and $3 \mu \mathrm{g} \mathrm{L}^{-1}$ 
measured in surface waters from this and Ruhr River (Germany) (Schröeder, 1995).

In absence of specific laboratory studies, available data show that, apart from aerobic degradation in the water column, sorption of SAS onto particulate matter can be regarded as one of the main processes occurring in the environment (Field et al., 1995). It also seems that this and other anionic and cationic surfactants may be accumulating in anaerobic compartments, especially WWTP sludge (García et al., 2000, 2005; Bruno et al., 2002). Recent studies, however, have demonstrated that some surfactants such as LAS can be effectively degraded in anoxic marine sediments, reaching degradation percentages up to $79 \%$ after 165 days (Lara-Martín et al., 2007a). Preferential degradation was observed to take place over short-chain homologues because of their lower hydrophobicity and affinity for the organic matter (Lara-Martín et al., 2007b). The anaerobic degradation pathway for LAS has also been described recently, consisting in the formation of sulfophenyl carboxylic acids (SPC) via oxidation of the alkyl chain by fumarate addition (LaraMartín et al., 2010). We hypothesize that SAS, having a chemical structure similar to LAS, could be degraded in anoxic marine sediments following the same mechanism.

The goals of this research were: a) to assess SAS sorption capacity on marine sediments by calculating partition coefficients for different homologues, b) to determine whether SAS are biodegradable or not in absence of oxygen in the marine environment, and c) to elucidate the structure of possible metabolites and to propose an anaerobic degradation pathway.

\section{Experimental section}

\subsection{Material and standards}

Formaldehyde, methanol, dichloromethane, acetone, and ethyl acetate were of chromatography quality and purchased from Scharlau (Barcelona, Spain); fosforic acid and sodium sulphate were purchased from Panreac (Barcelona, Spain) and water was Milli-Q quality. The solid-phase extraction (SPE) mini-columns used (500 mg) were supplied by Varian (Bond Elut $C_{18}$ ). The pure SAS internal standard $\left(C_{12}\right.$ SAS), the surrogate $\left(C_{10} S A S\right)$, and the commercial SAS mixtures were supplied by Clariant Produkte. Two different commercial mixtures were used, having the following homologue distribution and composition: $C_{14}(31 \%), C_{15}(32 \%), C_{16}(23 \%)$ and $C_{17}(14 \%)$ for the commercial mixture $10-20$, and $C_{14}(28 \%), C_{15}(28 \%), C_{16}(26 \%)$ and $C_{17}(18 \%)$ for the commercial mixture 20-20. Both mixtures also differ in the alkane disulfonate composition, being $1.5 \%$ for the first commercial mixture and $4.6 \%$ for the second, whereas the monosulfonic acid content was $18.7 \%$ and $18.5 \%$, respectively.

\subsection{Sampling and pretreatment}

Samples for both the anaerobic biodegradation assays and the sorption experiments were taken at Sancti Petri channel, a tidal marine channel which is $18 \mathrm{~km}$ length and connects the inner part of the salt marsh environment of the Bay of Cadiz with the Atlantic Ocean (SW Spain). First, in order to carry the sorption experiments, clean seawater (2.5 L amber glass bottles) and sediment (Van Veen grab) were collected from a non-polluted station at this area located in the west part of Sancti Petri channel $\left(36^{\circ} 23^{\prime} 21.62^{\prime \prime} \mathrm{N}, 6^{\circ} 12^{\prime} 27.40^{\prime \prime} \mathrm{W}\right)$. Total organic carbon content $(2.7 \%)$ in sediment was determined by dichromate oxidation, using the method proposed by Gaudette et al. (1974) with the El Rayis (1985) modification. Texture analysis was also performed ( $50.4 \%$ sand, $3.8 \%$ silt and $45.8 \%$ clay). Seawater physicochemical properties were: $\mathrm{pH}=7.86$, alkalinity $=2.86 \mathrm{mM}$, and salinity $=37.5$. Subsequently, both sediment and water samples were analysed in the laboratory to ensure that SAS

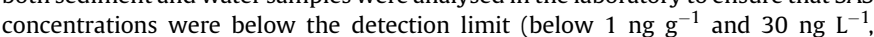
respectively). The seawater was also filtered through $0.22 \mu \mathrm{m}$ filters (Sterivac GP10, Millipore) to remove microorganisms and, therefore, to reduce the possible occurrence of biodegradation processes during the development of the sorption experiments.

Second, surface water (2.5 L amber glass bottles) and sediment cores (length $=60 \mathrm{~cm}$, diameter $=6 \mathrm{~cm}$ ) were collected in the central part of Sancti Petri channel $\left(36^{\circ} 28^{\prime} 20.80^{\prime \prime} \mathrm{N}, 6^{\circ} 10^{\prime} 52.95^{\prime \prime} \mathrm{W}\right)$ for the anaerobic biodegradation tests. This area is affected by wastewater discharges from an adjacent town (San Fernando, $>100000$ inhabitants). SAS concentrations in sediments were $0.6 \mathrm{mg} \mathrm{kg}^{-1}$. Seawater physicochemical properties were the same than those described above, whereas, in sediment, total organic carbon content was 3.0\% and particle distribution size was $14.0 \%$ sand and $86.0 \%$ silt + clay. Sections between 1 and $15 \mathrm{~cm}$ depth were selected from sediment cores to carry out the anaerobic biodegradation experiments.

\subsection{Sorption experiments}

Sorption tests were carried out following the same methodology previously used for studying the sorption of LAS homologues in marine sediments (Rubio et al., 1996). Two different SAS commercial mixtures (SAS 10-20 and 20-20) were tested. Polypropylene tubes (Herolab) were employed during these assays, being filled with $50 \mathrm{~mL}$ of filtered seawater at different SAS concentrations ( 1 and $10 \mathrm{mg} \mathrm{L}^{-1}$ ) and a certain amount of sediment $(0.5,5$ or $50 \mathrm{~g}$, dry weight). Incubation was carried out inside a thermostatic chamber at $25 \pm 0.2{ }^{\circ} \mathrm{C}$ and using an orbital shaker at $150 \mathrm{rpm}$ Then, tubes were centrifuged at $4000 \mathrm{~g}$ to separate the sediment from the aqueous fraction. Three different experiments were performed. First, we studied the time necessary to achieve the steady state in the sorption process. For that, tubes containing $50 \mathrm{~mL}$ of a solution of SAS in filtered seawater $\left(10 \mathrm{mg} \mathrm{L}^{-1}\right)$ and $0.5 \mathrm{~g}$ of sediment were sacrificed every $0,1,2,4,6,8,10$ and $24 \mathrm{~h}$ to measure SAS content in water. Second, partition coefficients were calculated for both SAS commercial mixtures using two solutions of SAS ( 1 and $10 \mathrm{mg} \mathrm{L}^{-1}$ ) and $0.5 \mathrm{~g}$ of sediment. Third, the effect of the water/sediment ratio was analysed using tubes containing a solution of SAS (10 $\mathrm{mg} \mathrm{L}^{-1}$ ) and different sediment amounts (5 and $50 \mathrm{~g}$ ).

\subsection{Anaerobic degradation experiments}

Anaerobic degradation tests were carried out following the same methodology previously used for studying the degradation of LAS in anoxic marine sediments (Lara-Martín et al., 2007a,b). All sample handling and incubation was carried out at $30^{\circ} \mathrm{C}$ in an anaerobic chamber filled with nitrogen. First, oxygen was removed from seawater using $\mathrm{N}_{2}$ and a redox indicator (resazurin) was added to confirm that anoxic conditions prevailed from the beginning to the end of the experiment. Sediment samples were mixed and homogenized. Degradation tests were carried out using 32 tightly sealed glass reactors ( $320 \mathrm{~mL}$ each) per experiment (independent experiments were conducted for the mixtures 10-20 and 20-20). These reactors were filled with anoxic water and sediment following a 3:1 ratio (240 mL of water and $70 \mathrm{~mL}$ of wet sediment) and leaving a headspace full of $\mathrm{N}_{2}(10 \mathrm{~mL})$. Reactors were then spiked to $10 \mathrm{mg} \mathrm{L}^{-1}$ of SAS and sacrificed by duplicate a different sampling times $(0,21,36,64,106$ and 166 days). Samples were fixed with $12 \mathrm{~mL}$ of formaldehyde to prevent any further degradation and centrifuged at $4000 \mathrm{~g}$ to separate sediment from water. Samples at time 0 were centrifuged and analysed $24 \mathrm{~h}$ after sterilization to allow the sorption process to reach the steady state. Later, SAS content was analysed in both fractions. Eight additional reactors ( 4 without SAS and 4 spiked with SAS but sterilized from the beginning) were used as control experiments to account for background contamination and non-biological processes. Microbial biomass was estimated by calculating methanogenesis and sulphate-reduction rates using the methodology described in a previous work (Lara-Martín et al., 2007a).

\subsection{Determination of SAS and possible metabolites}

Detailed information on the methodology used for SAS analysis can be found in Baena-Nogueras et al. (2013). Briefly, sediments were dried in a heater at $65^{\circ} \mathrm{C}$ until constant weight and milled and strained through a $63 \mu \mathrm{m}$ sieve. Then, $4 \mathrm{~g}$ aliquots were extracted by means of pressurized liquid extraction (PLE) using dichloromethane/methanol $1: 1$ at $100{ }^{\circ} \mathrm{C}$. Water samples (as well as sediment extracts) were purified and preconcentrated by solid-phase extraction (SPE) in an automated SPE Autotrace unit (Zymark). Elution of target compounds was carried out using methanol as solvent. After extracts were evaporated and redissolved in $1 \mathrm{~mL}$ of water/methanol 75:25, determination of SAS was performed by ultra-performance liquid chromatography coupled to quadrupole-time-flight mass spectrometry (UPLC-Q-ToF-MS) using a Waters Acquity - Synapt G2 tandem. Identification and quantification of SAS homologues $\left(C_{14}\right.$ to $\left.C_{17}\right)$ and possible metabolites formed during the anaerobic biodegradation experiment were achieved using standards (when available) and a combination of accurate mass measurement (error $<5 \mathrm{ppm}$ ) of molecular ions, specific retention times and characteristic ion fragments after MS/MS mode (collision energy $=30 \mathrm{eV}$ ).

\section{Results and discussion}

\subsection{Sorption of SAS on marine sediments}

Fig. 1a shows the evolution of SAS homologue concentrations in the aqueous phase during at sorption test. We can observe that the steady state is achieved in less than $2 \mathrm{~h}$. This is in agreement with previous studies on sorption of anionic surfactants such as linear alkylbenzene sulfonates (LAS) reporting that $4 \mathrm{~h}$ are enough to reach the equilibrium during sorption assays (Rubio et al., 1996; Westall et al., 1999). In any case, the following sorption experiments (1-6) lasted $24 \mathrm{~h}$ to ensure equilibrium. Fig. 1b shows sediment-water partition coefficients for two commercial mixtures of SAS. To the best of our knowledge, these are the first data 

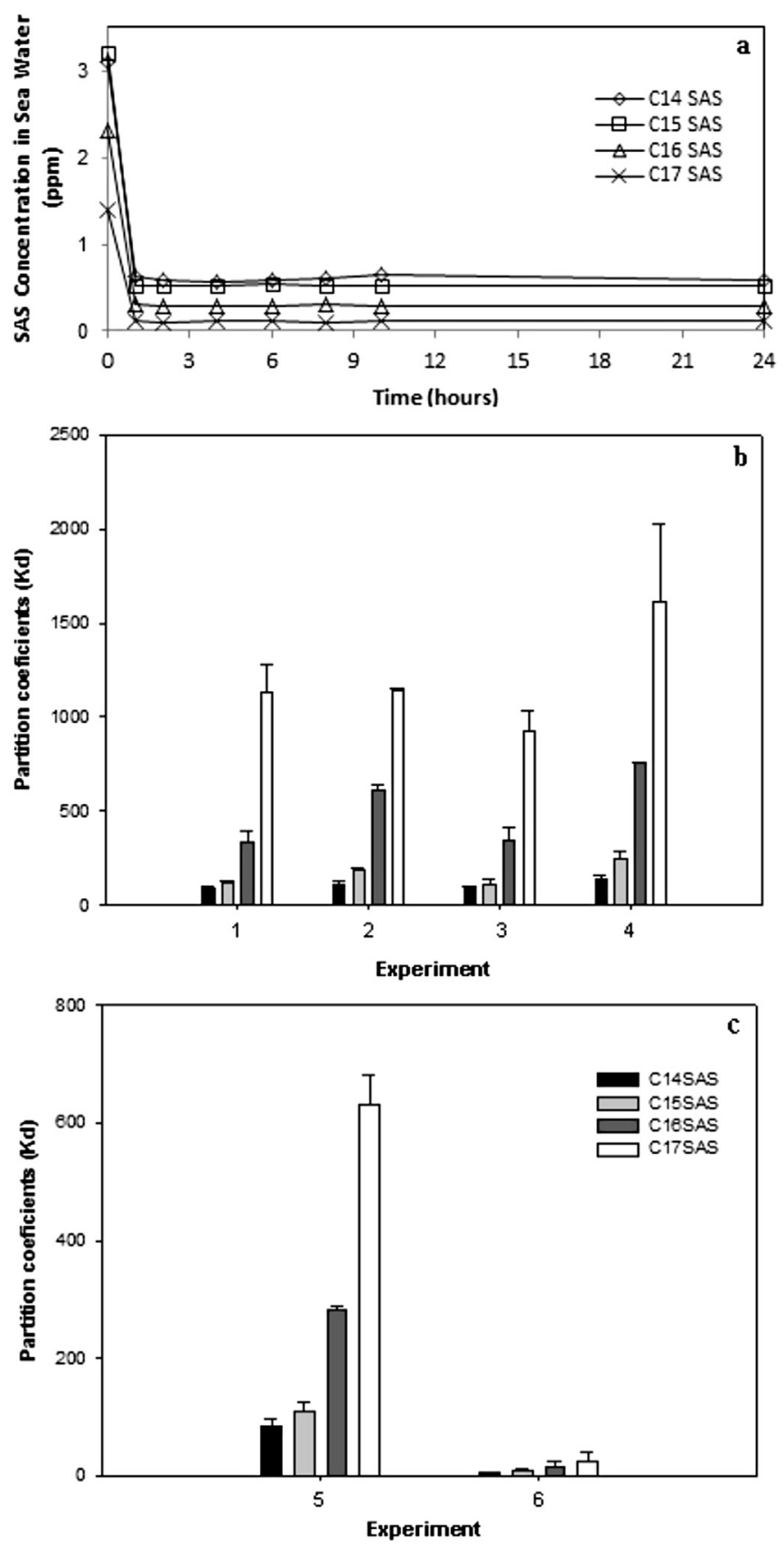

Fig. 1. a) Concentration of SAS homologues in water vs time during a sorption experiment ( $10 \mathrm{mg} \mathrm{L}^{-1}$ of SAS $10-20,0.5 \mathrm{~g}$ of sediment), and sediment-water partition coefficients using b) different SAS concentrations (SAS 10-20: test 1 at $1 \mathrm{mg} \mathrm{L}^{-1}$, test 2 at $10 \mathrm{mg} \mathrm{L}^{-1}$, SAS $20-20$ : test 3 at $1 \mathrm{mg} \mathrm{L}^{-1}$, test 4 at $10 \mathrm{mg} \mathrm{L}^{-1}$ ), and c) different amounts of sediments ( $10 \mathrm{mg} \mathrm{L}^{-1}$ of SAS $20-20$, test 5 at $5 \mathrm{~g}$, test 6 at $50 \mathrm{~g}$ ). available on the sorption capacity of this surfactant on sediments. Sorption may occur predominantly by means of hydrophobic mechanisms, as the partition coefficient greatly increases towards longer alkyl chain homologues. Thus, there was an increment in the sorption capacity when moving from $\mathrm{C}_{14}\left(K_{\mathrm{d}}=141 \mathrm{~L} \mathrm{~kg}^{-1}\right)$ to $\mathrm{C}_{17}$ SAS $\left(K_{\mathrm{d}}=1608 \mathrm{~L} \mathrm{~kg}^{-1}\right)$. This behaviour has been already reported for other related anionic surfactants such as LAS (Rubio et al., 1996), where the partition coefficient in marine sediments increased from $78 \pm 18$ to $1145 \pm 263 \mathrm{~L} \mathrm{~kg}^{-1}$ for different homologues $\left(C_{10}\right.$ to $\left.C_{13}\right)$.

A t-student test $(p>0.05)$ was used to compare data from the different experiments. Sorption was found to be linear between the two concentrations tested ( 1 and $10 \mathrm{mg} \mathrm{L}^{-1}$ ) as there were no significant differences (experiment 1 vs experiments 2, 3 and 4 ) in the partition coefficient values (Fig. 1b) which implies that the influence of the amount of alkane disulfonates (1.5 vs $4.6 \%$, respectively) in the solution was negligible over the sorption capacity of SAS homologues. This range of concentrations was selected taking into account concentrations previously measured in Guadalete River (Baena-Nogueras et al., 2013), as well as the concentration (10 $\mathrm{mg} \mathrm{L}^{-1}$ ) used in the anaerobic degradation assays. Significant differences, however, were found when comparing different amounts of sediment used during the sorption assays (Fig. 1c). Partition coefficients decreased when $5 \mathrm{~g}$ of sediment (experiment 5) were used instead of $0.5 \mathrm{~g}$, and more remarkably when using $50 \mathrm{~g}$ (experiment 6 ). There was, therefore, an apparent dependence of the partition coefficients on the water/sediment ratios used, which has been previously reported by other authors performing batch sorption studies (Di Toro, 1985; Westall et al., 1999).

\subsection{Anaerobic biodegradation of SAS}

Fig. 2a and $\mathrm{b}$ shows a mass balance during the anaerobic biodegradation assays of SAS for both commercial mixtures (10-20 and 20-20). Concentrations of SAS homologues were measured in water and sediment during the experiments $(0,21,36,64,106$ and 166 days). Between 30 and 39\% of the total SAS amount was in the aqueous phase and, therefore, easily bioavailable at the beginning of the experiment. After 166 days, there was no reduction in the levels of SAS in any of the abiotic controls previously fixed with formaldehyde. Redox potential was also monitored, being between -170 and $-380 \mathrm{mV}$. Additionally, anaerobic conditions were confirmed by means of a redox indicator (resazurin) and measuring sulphate-reduction and methanogenesis rates. The methane production, measured as $\mu \mathrm{mol}$ of $\mathrm{CH}_{4}$ accumulated per gram of sediment, increased during the first 30 days of incubation (Fig. 3a). After that, the total methane produced remained virtually constant in the microcosms until the end of the experiment. Although the two commercial mixtures of SAS (20-10 and 20-20) behaved similar, the 20-20 always showed a $25-30 \%$ higher $\mathrm{CH}_{4}$. On the other hand, the production of $\mathrm{H}_{2} \mathrm{~S}$ proceeding from the

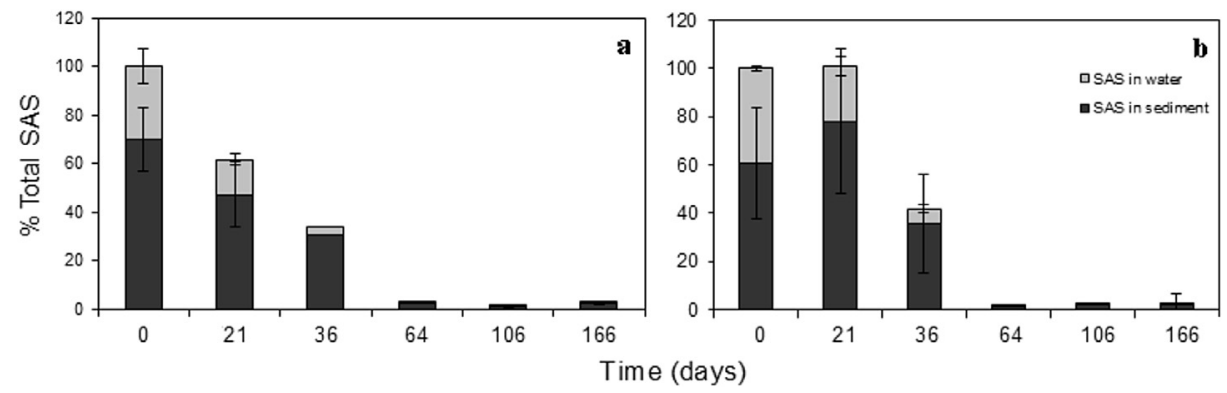

Fig. 2. Mass balance during the anaerobic degradation assays for two commercial mixtures of SAS: a) 10-20, and b) 20-20. 

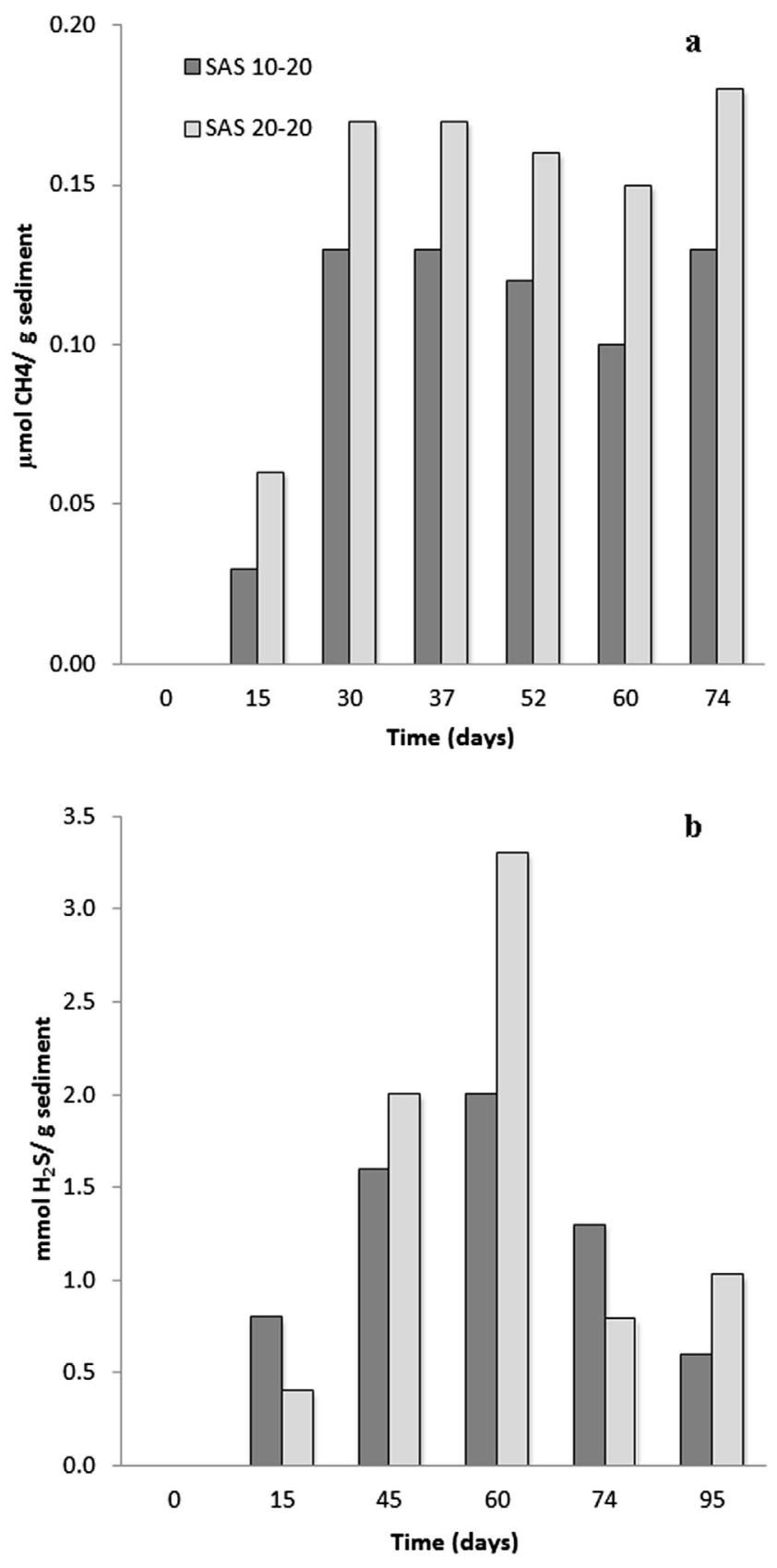

c

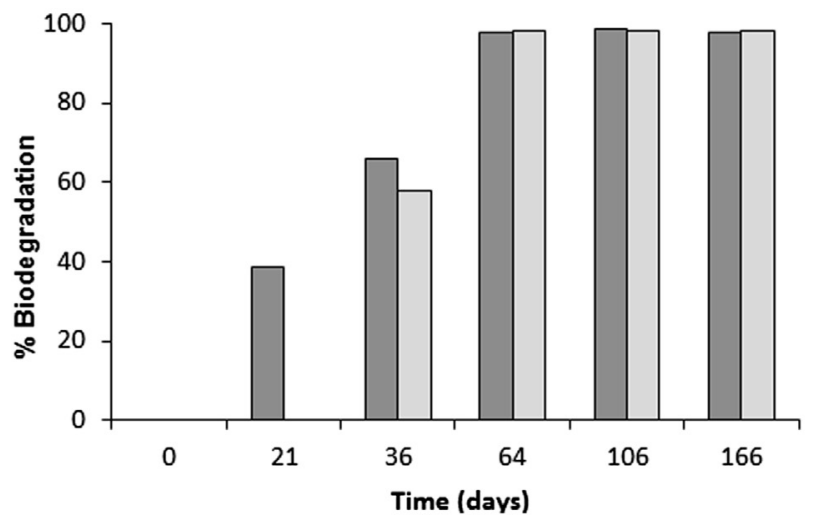

sulphate-reduction raised during two months and decreased later towards the end of the experiments (Fig. 3b). In marine sediments sulphate-reducers microorganisms are predominant over methanogens (Lara-Martín et al., 2007a; Köchling et al., 2011). Methanogenic activity seems to be based on the degradation of the organic matter present in the polluted sediments, finishing when that is depleted. Nevertheless, the time-course of sulphatereducing activity run in parallel with the SAS degradation (Fig. 3c). Considering that many genera of sulphate-reducers bacteria, such as Desulfobacter, Desulfobacterium, Desulfosarcina or Desulfococcu, are acetate oxidizers (Madigan et al., 2000), it can be assumed that these microorganisms use the acetate released in the SAS degradation as electron donors for the sulphate reduction. Consequently, the sulphate-reducing activity seems to be better indicator than methanogenesis of the SAS degradation, especially in marine environments where the sulphate concentration is greater than in freshwater environments.

Regarding the evolution of SAS during the assays, no degradation was observed during the first 21 days in some reactors from the experiment carried out with the commercial mixture 20-20 (Fig. 2b). This may correspond to an acclimation period required by the bacteria before starting the degradation process, as it was previously observed by our group when conducting LAS anaerobic degradation experiments in marine sediments (Lara-Martín et al., 2007a). Additionally, sediments are heterogeneous, so they may contain different types and amounts of bacteria in every reactor in spite that we try to homogenize them before starting the experiments. This can be clearly observed in Fig. 3a and b, where sulphate-reduction and methanogenesis rates show opposite trends when comparing reactors using SAS $10-20$ and $20-20$ at day 15 . In any case, after 36 days from the beginning of the incubation, the original amount of SAS (10-20 and 20-20) was reduced by more than $50 \%$, reaching degradation percentages of $98 \%$ after 64 days. These data were fitted to a first order kinetic model, showing half-live values of 11 days for both commercial mixtures. These results can be compared with those obtained by Bruno and co-workers (Bruno et al., 2002), who reported SAS removal percentages between 5 and 13\% after 14 days of anaerobic digestion of WWTP sludge. Differences in SAS degradation efficiencies are probably due to the short incubation time that they used, as well as significant differences in bacteria populations in the sludge digester. In fact, a previous study carried out by our group (LaraMartín et al., 2007a) proposed Sedimentibacter sp., a bacterial specie specific for sediments, as a possible candidate for LAS anaerobic biodegradation. It should be also highlighted that, as expected, removal of SAS in absence of oxygen is a much slower process than in aerobic reactors (e.g., 98\% in 64 days in our case versus $84 \%$ in 90 min according to Field et al., 1995).

Fig. $4 \mathrm{a}$ and $\mathrm{b}$ shows the evolution in the relative percentage of SAS homologues in water and sediment during both degradation experiments (10-20 and 20-20, respectively). The same trend that was observed in sorption experiments (an increase in the sorption capacity of SAS towards longer alkyl chain homologues) was also observed during the degradation assays. As a consequence of this, aqueous phase was enriched in $\mathrm{C}_{14}$ SAS from the beginning ( $25 \%$ more than in the commercial standards, up to $187 \mu \mathrm{g} \mathrm{L}^{-1}$ ) while most hydrophobic homologues were predominant in the particulate phase. The unequal distribution of SAS homologues between the different phases influences their bioavailability and, therefore, their anaerobic biodegradation in marine sediments. As

Fig. 3. a) Methane production ( $\mu$ mol of accumulated $\mathrm{CH}_{4}$ per gram of sediment) during anaerobic degradation assays, b) sulfate-reduction activity (mmol of $\mathrm{H}_{2} \mathrm{~S}$ produced per gram of sediment), and c) percentage of biodegradation. 
Water
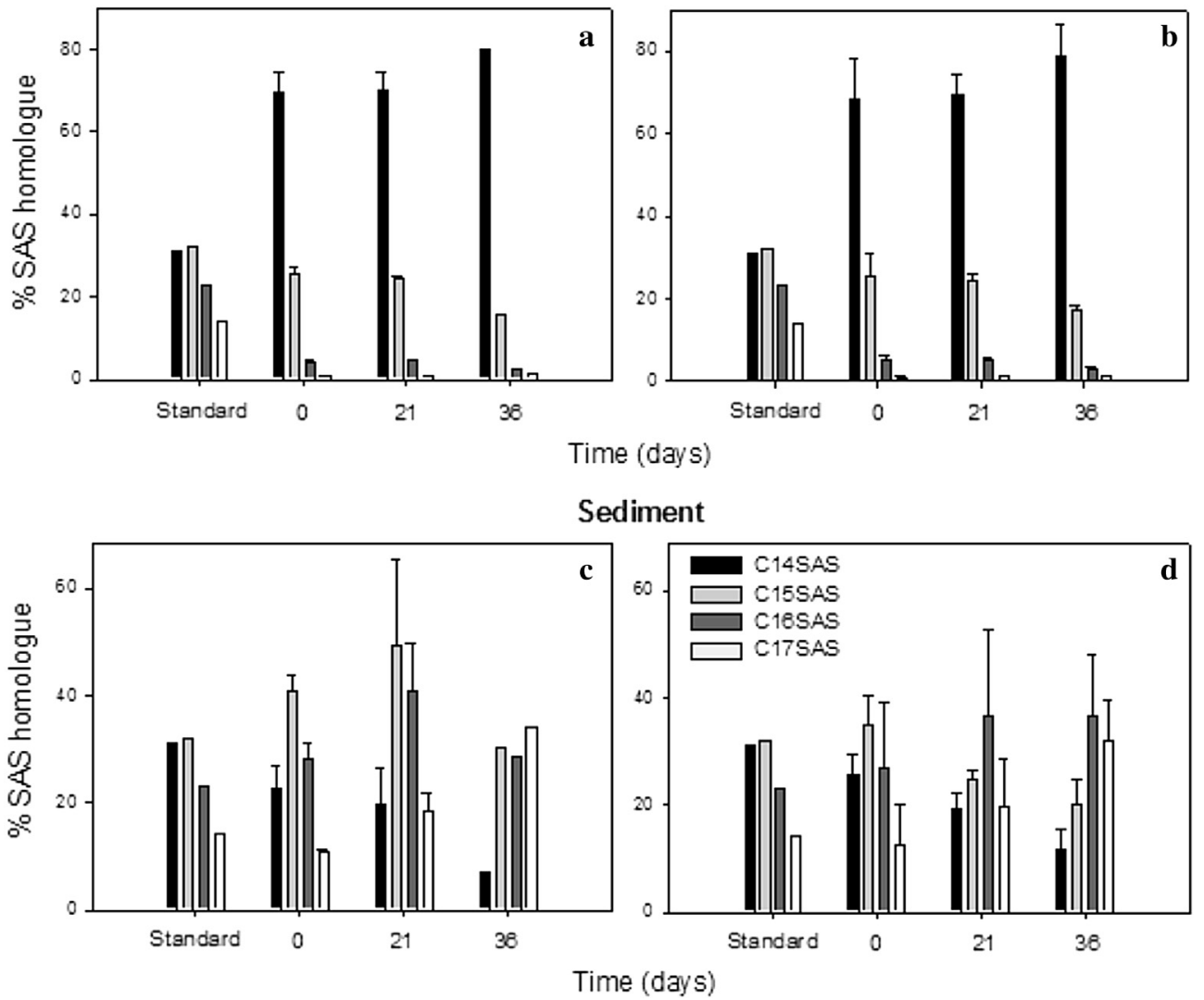

Fig. 4. Evolution in the relative percentage of SAS homologues in water (a and b) and sediment (c and d) for two commercial mixtures (10-20 and 20-20).

an example, $\mathrm{C}_{14}$ SAS was released from sediments during the course of experiment so its relative amount in sediment decreased from $26 \%\left(>1 \mathrm{mg} \mathrm{kg}^{-1}\right)$ to $6 \%\left(120 \mu \mathrm{g} \mathrm{kg}^{-1}\right)$ after 36 days. Aqueous concentrations of the most hydrophobic $\mathrm{C}_{17} \mathrm{SAS}$, which is firmly attached to sediments, were always much lower (up to $2 \mu \mathrm{g} \mathrm{L}^{-1}$ ) than those for short alkyl chain homologues $\left(\mathrm{C}_{14}\right.$ and $\mathrm{C}_{15}$ ) (Fig. $4 \mathrm{a}$ and $b$ ), so its degradation was more limited and explains why long alkyl chain SAS homologues $\left(C_{16}\right.$ and $\left.C_{17}\right)$ were accumulated in the sediment towards the end of the experiment (e.g., $\mathrm{C}_{17}$ SAS increases from 11 to $34 \%$ after 36 days, which corresponds to a reduction in its

Table 1

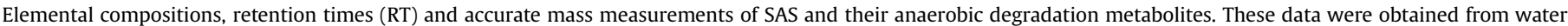
samples ( $t=21-36$ days) from the anaerobic degradation experiments performed with both commercial mixtures.

\begin{tabular}{|c|c|c|c|c|c|c|}
\hline Compound & Elemental composition & $\mathrm{RT}(\min )$ & Theoretical mass $(m / z)$ & Experimental mass $(\mathrm{m} / \mathrm{z})$ & Error (mDa) & Error (ppm) \\
\hline $\mathrm{C}_{9} \mathrm{SC}$ & $\mathrm{C}_{10} \mathrm{H}_{19} \mathrm{SO}_{5}$ & 5.553 & 251.0953 & 251.0950 & -0.3 & -1.2 \\
\hline $\mathrm{C}_{10} \mathrm{SC}$ & $\mathrm{C}_{11} \mathrm{H}_{21} \mathrm{SO}_{5}$ & 4.844 & 265.1110 & 265.1101 & -0.9 & -3.4 \\
\hline $\mathrm{C}_{11} \mathrm{SC}$ & $\mathrm{C}_{12} \mathrm{H}_{23} \mathrm{SO}_{5}$ & 5.216 & 279.1266 & 279.1271 & 0.5 & 1.8 \\
\hline $\mathrm{C}_{12} \mathrm{SC}$ & $\mathrm{C}_{13} \mathrm{H}_{25} \mathrm{SO}_{5}$ & 5.722 & 293.1423 & 293.1417 & -0.6 & -2 \\
\hline $\mathrm{C}_{13} \mathrm{SC}$ & $\mathrm{C}_{14} \mathrm{H}_{27} \mathrm{SO}_{5}$ & 5.820 & 307.1579 & 307.1575 & -0.4 & -1.3 \\
\hline $\mathrm{C}_{14} \mathrm{SC}$ & $\mathrm{C}_{15} \mathrm{H}_{29} \mathrm{SO}_{5}$ & 5.908 & 321.1736 & 321.1726 & -1 & -3.1 \\
\hline $\mathrm{C}_{15} \mathrm{SC}$ & $\mathrm{C}_{16} \mathrm{H}_{31} \mathrm{SO}_{5}$ & 6.297 & 335.1892 & 335.1888 & -0.4 & -1.2 \\
\hline $\mathrm{C}_{16} \mathrm{SC}$ & $\mathrm{C}_{17} \mathrm{H}_{33} \mathrm{SO}_{5}$ & 6.315 & 349.2049 & 349.2048 & -0.1 & -0.3 \\
\hline $\mathrm{C}_{17} \mathrm{SC}$ & $\mathrm{C}_{18} \mathrm{H}_{35} \mathrm{SO}_{5}$ & 6.518 & 363.2205 & 363.2200 & -0.5 & -1.4 \\
\hline $\mathrm{Me}-\mathrm{C}_{14} \mathrm{SC}$ & $\mathrm{C}_{15} \mathrm{H}_{29} \mathrm{SO}_{5}$ & 5.908 & 321.1736 & 321.1726 & -1 & -3.1 \\
\hline $\mathrm{Me}-\mathrm{C}_{15} \mathrm{SC}$ & $\mathrm{C}_{16} \mathrm{H}_{31} \mathrm{SO}_{5}$ & 6.297 & 335.1892 & 335.1888 & -0.4 & -1.2 \\
\hline $\mathrm{Me}-\mathrm{C}_{16} \mathrm{SC}$ & $\mathrm{C}_{17} \mathrm{H}_{33} \mathrm{SO}_{5}$ & 6.315 & 349.2049 & 349.2048 & -0.1 & -0.3 \\
\hline $\mathrm{Me}-\mathrm{C}_{17} \mathrm{SC}$ & $\mathrm{C}_{18} \mathrm{H}_{35} \mathrm{SO}_{5}$ & 6.518 & 363.2205 & 363.2200 & -0.5 & -1.4 \\
\hline $\mathrm{Me}-\mathrm{C}_{18} \mathrm{SC}$ & $\mathrm{C}_{19} \mathrm{H}_{37} \mathrm{SO}_{5}$ & 6.634 & 377.2362 & 377.2345 & 1.7 & 4.5 \\
\hline $\mathrm{Me}-\mathrm{C}_{19} \mathrm{SC}$ & $\mathrm{C}_{20} \mathrm{H}_{39} \mathrm{SO}_{5}$ & 6.820 & 391.2518 & 391.2509 & -0.9 & -2.3 \\
\hline $\mathrm{Me}-\mathrm{C}_{16} \mathrm{SdC}$ & $\mathrm{C}_{18} \mathrm{H}_{33} \mathrm{SO}_{7}$ & 5.908 & 393.1947 & 393.1954 & 0.7 & 1.8 \\
\hline $\mathrm{Me}-\mathrm{C}_{17} \mathrm{SdC}$ & $\mathrm{C}_{19} \mathrm{H}_{35} \mathrm{SO}_{7}$ & 6.094 & 407.2103 & 407.2112 & 0.9 & 2.2 \\
\hline $\mathrm{Me}-\mathrm{C}_{18} \mathrm{SdC}$ & $\mathrm{C}_{20} \mathrm{H}_{37} \mathrm{SO}_{7}$ & 6.332 & 421.2260 & 421.2249 & -1.1 & -2.6 \\
\hline $\mathrm{Me}-\mathrm{C}_{19} \mathrm{SdC}$ & $\mathrm{C}_{21} \mathrm{H}_{39} \mathrm{SO}_{7}$ & 6.466 & 435.2416 & 435.2405 & -1.1 & -2.5 \\
\hline $\mathrm{C}_{14} \mathrm{SAS}$ & $\mathrm{C}_{14} \mathrm{H}_{29} \mathrm{SO}_{3}$ & 6.767 & 277.1837 & 277.1839 & 0.2 & 0.7 \\
\hline $\mathrm{C}_{15}$ SAS & $\mathrm{C}_{15} \mathrm{H}_{31} \mathrm{SO}_{3}$ & 6.890 & 291.1994 & 291.996 & 0.2 & 0.7 \\
\hline $\mathrm{C}_{16} \mathrm{SAS}$ & $\mathrm{C}_{16} \mathrm{H}_{33} \mathrm{SO}_{3}$ & 7.245 & 305.2150 & 305.2155 & 0.5 & 1.6 \\
\hline $\mathrm{C}_{17}$ SAS & $\mathrm{C}_{17} \mathrm{H}_{35} \mathrm{SO}_{3}$ & 7.565 & 319.2307 & 319.2307 & 0 & 0 \\
\hline
\end{tabular}



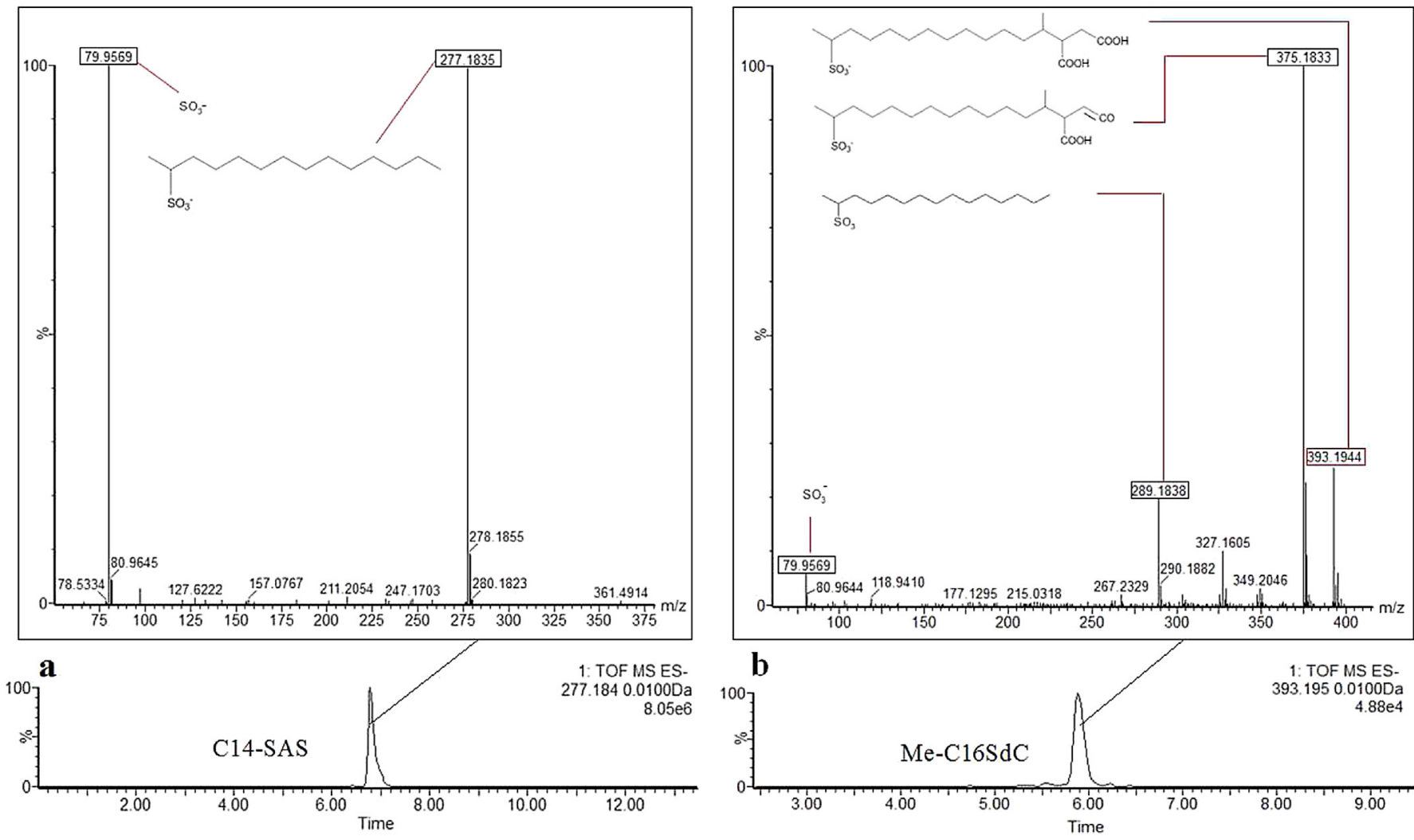

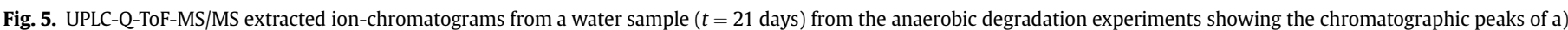

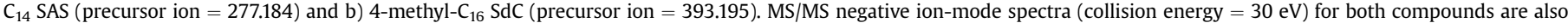
shown, as well as the structure of the molecular ions and selected fragments.

concentration only from 393 to $320 \mu \mathrm{g} \mathrm{kg}^{-1}$ ) (Fig. 4c and d). This type of distributions of SAS homologues have been confirmed to occur when comparing data from surface waters and surface sediments from Guadalete River, and wastewater and sludge from Puerto Real WWTP (SW Spain) (Baena-Nogueras et al., 2013). They are also common for other surfactant homologues such as those for LAS and alcohol ethoxylates (Lara-Martín et al., 2008b). Moreover, similar differential degradation was previously observed for LAS homologues during an anaerobic degradation experiment carried out using sediments from the same area (Lara-Martín et al., 2007b).

\subsection{Elucidation of the structure of SAS metabolites and degradation pathway}

Table 1 shows the elemental composition, retention time and accurate mass of SAS homologues and all the degradation intermediates that were identified by UPLC-q-TOF-MS. In agreement with recent studies on anaerobic biodegradation of n-alkanes (Aitken et al., 2013) and other anionic surfactants such as LAS (Lara-Martín et al., 2010), the decrease in the concentrations of the parent compounds that were observed thorough the experiments were related with the appearance of polar metabolites, mainly sulfocarboxylic acids (SC), but also other products such as methyl-sulfocarboxylic acids (Me-SC) and methyl-sulfodicarboxylic acids (Me-SdC). These degradation products, however, were not stable enough to be detected throughout the whole time of the experiment, but mainly between 21 and 36 days, when most of the degradation process takes place. Their identification was based on mass accurate measurement of the molecular ions (error $<5 \mathrm{ppm}$ ), the fact that their retention times were shorter than those for SAS homologues as a consequence of their greater polarity, and that none of these new compounds were detected in abiotic controls, where concentration of SAS remained stable over the entire duration of the experiment. Additionally, using MS/MS mode, we were able to elucidate the molecular structure of the degradation products and, by fragmenting molecular ions for SAS and their degradation products (see Table 1), find out a common fragment $m / z 79.9568$, corresponding to the sulfonate group (Fig. 5a and b).

Fig. 6A-F shows extracted UPLC-q-TOF-MS chromatograms for $\mathrm{C}_{14}$ SAS and some selected metabolites, as well as the proposed anaerobic degradation pathway for SAS in marine sediments. This pathway is similar to that previously described for LAS in a recent paper by our research group (Lara-Martín et al., 2010), and confirms that the following mechanism, also proposed to explain the degradation of several types hydrocarbons (Callaghan et al., 2010; Mbadinga et al., 2011), is predominant in the marine environment. The first stage consists in the formation of dicarboxylic acids (Me-SdC) by the addition of fumarate to the subterminal carbon atom (C-2) of the alkyl chain of SAS (Fig. 6A and B). As it was previously discussed in the case of LAS, fumarate addition to $\mathrm{C}-2$ is energetically favoured over $\mathrm{C}-1$. The next stage in the degradation pathway (Fig. 6C) results in the appearance of Me-SC, due to a Cskeleton rearrangement similar to that described for the anaerobic degradation of alkanes (Wilkes et al., 2002). Briefly, it consists on the migration of the carboxyl group from $\mathrm{C}-3$ to $\mathrm{C}-2$ and a subsequent decarboxylation due to the release of the carboxyl group in C-1. Direct decarboxylation of Me-SdC instead may be also possible. Finally, the resulting products undergo succesive $\beta$-oxidations, which can take place in absence of oxygen with protons $/ \mathrm{H}^{+}$as electron acceptors and generate sulfocarboxylic acids (Fig. 6D-F). During this sequence, a C3 unit is released (Fig. 6D and E), which may be used for the regeneration of fumarate and later activation of 


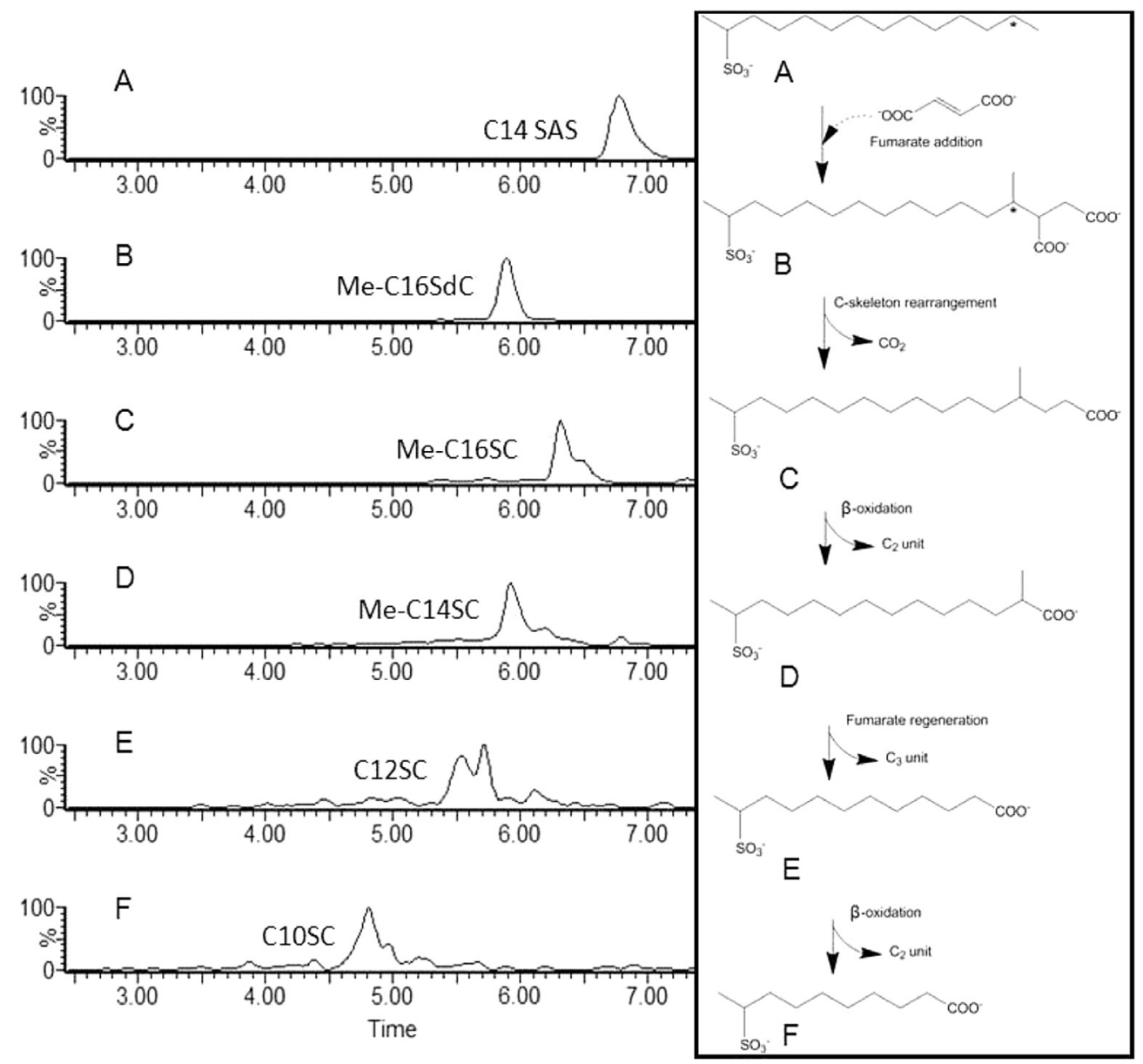

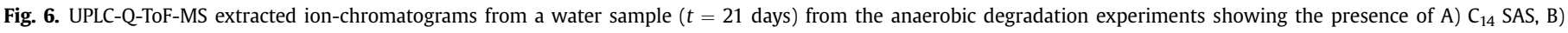

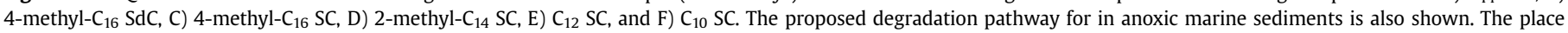
where the fumarate addition takes place $(\mathrm{C}-2)$ is marked with an asterisk.

other SAS molecules, according to Wilkes et al. (2002) and Davidova et al. (2005).

\section{Conclusions}

This paper shows the first available information on the environmental behaviour of SAS, one of the main surfactants used in dishwashing and cleaning products, in the marine environment. Sorption of SAS on sediments follows a hydrophobic mechanism as the partition coefficient $\left(K_{\mathrm{d}}\right)$ increases towards those homologues having longer alkyl chains (from $141 \mathrm{~L} \mathrm{~kg}^{-1}$ for $C_{14}$ to $1753 \mathrm{~L} \mathrm{~kg}^{-1}$ for $C_{17}$ ). Differential sorption between homologues also influences the biodegradation of SAS in marine sediments. Thus, after 166 days of incubation in absence of oxygen, total biodegradation of SAS reached up to $98 \%$, the major fraction on the non-degraded surfactant corresponding to most hydrophobic and, hence, less bioavailable, $\mathrm{C}_{16}$ and $\mathrm{C}_{17}$ homologues. As a consequence of this study, the environmental fate of SAS should be re-evaluated as previous degradation experiments carried out in anaerobic sludge digesters showed no evidence of degradation of this and other anionic surfactants. Moreover, an anaerobic degradation pathway of SAS was proposed here for the first time too, consisting on the formation of sulfocarboxylic acids after an initial fumarate attack of the alkyl chain and successive $\beta$-oxidations. This is a confirmation that this type of mechanism, previously observed in marine sediments for other compounds such as LAS and hydrocarbons, is widely extended.

\section{Acknowledgements}

We express our gratitude to E. de Miguel for his technical support with the LC-MS systems. We also thank Clariant Produkte (OT 2010/105) for providing funding for this research. Part of this work has been also carried out within two regional research projects (RNM 5417 and RNM 6613) funded by Consejería de Innovación, Ciencia y Empresa (Junta de Andalucía).

\section{References}

Aitken, C.M., Jones, D.M., Maguire, M.J., Gray, N.D., Sherry, A., Bowler, B.F.J., Ditchfield, A.K., Larter, S.R., Head, I.M., 2013. Evidence that crude oil alkane activation procedes by different mechanism under sulfate-reducing and methanogenic conditions. Geochim. Cosmochim. Acta 109, 162-174.

Baena-Nogueras, R.M., González-Mazo, E., Lara-Martín, P.A., 2013. Determination and occurrence of secondary alkane sulfonates (SAS) in aquatic environments. Environ. Pollut. 176, 151-157.

Bruno, F., Curini, R., Di Corcia, A., Fochi, I., Nazzari, M., Samperi, R., 2002. Determination of surfactants and some of their metabolites in untreated and anaerobically digested sewage sludge by subcritical water extraction followed by liquid chromatography-mass spectrometry. Environ. Sci. Technol. 36, 4156-4161.

Callaghan, A.V., Davidova, I.A., Savage-Ashlock, K., Parisi, V.A., Gieg, L.M. Suflita, J.M., Kukor, J.J., Wawrik, B., 2010. Diversity of Benzyl- and Alkylsuccinate synthase genes in hydrocarbon-impacted environments and enrichment cultures. Environ. Sci. Technol. 44, 7287-7294. 
Davidova, I.A., Gieg, L.M., Nanny, M., Kropp, K.G., Suflita, J.M., 2005. Stable isotopic studies of $n$-alkane metabolism by a sulfatereducing bacterial enrichment culture. Appl. Environ. Microbiol. 71, 8174-8182.

Di Toro, D.M., 1985. A particle interaction model of reversible organic chemical sorption. Chemosphere 14, 1503-1538.

El Rayis, O.A., 1985. Re-assessment of the titration method for the determination of organic carbon in recent sediments. Rapp. Comm. Int. Mer. Medit. 29, 45-47.

Field, J.A., Field, T.M., Poiger, T., Giger, W., 1994. Determination of secondary alkane sulfonates in sewage wastewaters by solid-phase extraction and injection-port derivatization gas chromatography/mass spectrometry. Environ. Sci. Technol, 28, 497-503.

Field, J.A., Field, T.M., Poiger, T., Siegrist, H., Giger, W., 1995. Fate of secondary alkane sulfonate surfactants during municipal wastewater treatment. Water Res. 29, 1301-1307.

García, M.T., Campos, E., Sánchez-Leal, J., Ribosa, I., 2000. Anaerobic degradation and toxicity of commercial cationic surfactants in anaerobic screening tests. Chemosphere 41, 705-710.

García, M.T., Campos, E., Ribosa, I., Latorre, A., Sánchez-Leal, J., 2005. Anaerobic digestion of linear alkylbenzene sulfonates: biodegradation kinetics and metabolite analysis. Chemosphere 60, 1636-1643.

Gaudette, H.E., Flight, W.R., Torner, L., Folger, D.W., 1974. An inexpensive titration method for the determination of organic carbon in recent sediments. J. Sediment. Petrol. 44, 249-253.

HERA project, 2005. Secondary Alkane Sulfonates (SAS) in Human and Environmental Risk Assessment on Ingredients of Household Cleaning Products (Environmental Risk Assesment Report. Brussels, Belgium).

Köchling, T., Lara-Martín, P.A., González-Mazo, E., Amils, R., Sanz, J.L., 2011. Microbial community composition of anaerobic marine sediments in the Bay of Cádiz (Spain). Int. Microbiol. 14, 143-154.

Kolpin, Dana W., Furlong, Edward T., Meyer, Michael T., Thurman, E. Michael, Zaugg, Steven D., Barber, Larry B., Buxton, Herbert T., 2002. Pharmaceuticals, hormones, and other organic wastewater contaminants in U.S Streams, 1999-2000: a National Reconnaissance. Environ. Sci. Technol. 36, $1202-1211$.
Lara-Martín, P.A., Gómez-Parra, A., Köchling, T., Sanz, J.L., González-Mazo, E., 2007a. Anaerobic degradation of linear alkylbenzene sulfonates in coastal Marine sediments. Environ. Sci. Technol. 41, 3573-3579.

Lara-Martín, P.A., Gómez-Parra, A., Köchling, T., Sanz, J.L., González-Mazo, E., 2007b. Monitoring the primary biodegradation of linear alkylbenzene sulfonates and their coproducts in anoxic sediments using liquid chromatography-mass spectrometry. Environ. Sci. Technol. 41, 3580-3586.

Lara-Martín, P.A., Gómez-Parra, A., González-Mazo, E., 2008a. Reactivity and fate of synthetic surfactants in aquatic environments. Trends Anal Chem. 27, 684-695.

Lara-Martín, P.A., Gómez-Parra, A., González-Mazo, E., 2008b. Sources, transport and reactivity of anionic and non-ionic surfactants in several aquatic ecosystems in SW Spain: a comparative study. Environ. Pollut. 156, 36-45.

Lara-Martín, P.A., Gómez-Parra, A., Sanz, J.L., González-Mazo, E., 2010. Anaerobic degradation pathway of linear alkylbenzene sulfonates (LAS) in sulfatereducing marine sediments. Environ. Sci. Technol. 44, 1670-1676.

Madigan, M.T., Martinko, J.M., Parker, J., 2000. Brock Biology of Microorganisms (chapter 13), ninth ed. Prentice-Hall, Inc, Upper Saddle River, New Jersey.

Mbadinga, S.M., Wang, L.Y., Zhou, L., Liu, J.F., Gu, J.D., Mu, B.Z., 2011. Microbia communities involved in anaerobic degradation of alkanes. Int. Biodeterior. Biodegrad. 65, 1-13.

Rubio, J.A., González-Mazo, E., Gómez-Parra, A., 1996. Sorption of linear alkylbenzenesulfonates (LAS) on marine sediment. Mar. Chem. 54, 171-177.

Schröeder, F.R. 1995. Concentrations of anionic surfactants in receiving riverine water: results of a long-term monitoring programme in the river Rur. Tenside Surfact. Det. 32, 492-497.

Swisher, R.D., 1964. Transient intermediates in the biodegradation of straight chain alkylbenzene sulfonates (ABS). J. Water Pollut. Control Fed. 35, 1557-1564.

Thysse, G.J.E., Wanders, T.H., 1974. Initial steps in the degradation of n-alkane-1sulfonates by Pseudomonas. J. Microbiol. Serol. 40, 25-37.

Westall, J.C., Chen, H., Zhang, W., Brownawell, B.J., 1999. Sorption of linear alkylbenzenesulfonates on sediment materials. Environ. Sci. Technol. 33, 3110-3118.

Wilkes, H., Rabus, R., Fischer, T., Armstroff, A., Behrends, A., Widdel, F., 2002 Anaerobic degradation of $n$-hexane in a denitrifying bacterium: further degradation of the initial intermediate (1-methylpentyl) succinate via C-skeleton rearrangement. Arch. Microbiol. 177, 235-243. 